\title{
Precursors and preinvasive lesions of the breast: the role of molecular prognostic markers in the diagnostic and therapeutic dilemma
}

\author{
Flora Zagouri, Theodoros N Sergentanis and George C Zografos*
}

Address: Breast Unit, 1st Department of Propaedeutic Surgery, Hippokratio Hospital, University of Athens, Athens, Greece

Email: Flora Zagouri - florazagouri@yahoo.co.uk; Theodoros N Sergentanis - tsergentanis@yahoo.gr;

George C Zografos* - gzografo@med.uoa.gr

* Corresponding author

World Journal of Surgical Oncology 2007, 5:57 doi:10.1186/1477-7819-5-57

This article is available from: http://www.wjso.com/content/5///57

(c) 2007 Zagouri et al; licensee BioMed Central Ltd.

This is an Open Access article distributed under the terms of the Creative Commons Attribution License (http://creativecommons.org/licenses/by/2.0), which permits unrestricted use, distribution, and reproduction in any medium, provided the original work is properly cited.

\begin{abstract}
Precursors and preinvasive lesions of the breast include atypical ductal hyperplasia (ADH), ductal carcinoma in situ (DCIS), and lobular neoplasia (LN). There is a significant debate regarding the classification, diagnosis, prognosis and management of these lesions. This review article describes the current theories regarding the pathogenesis and molecular evolution of these lesions. It reviews the implication of a variety of molecules in the continuum of breast lesions: estrogen receptors (ERalpha and ER-beta), c-erb-B2 (Her2/neu), p53, Ki-67, bcl-2, E-cadherin, transforming growth factorbeta (TGF-beta), p27 (Kipl), pl6 (INK4a), p2I (Wafl), vascular endothelial growth factor (VEGF). With respect to the aforementioned molecules, this article reviews their pathophysiological importance, and puts the stress on whether they confer additional risk for invasive breast cancer or not. This knowledge has the potential to be of importance in the therapeutic decisions presenting in the common clinical practice.
\end{abstract}

\section{Background}

Precursors and preinvasive lesions of the breast, which include atypical ductal hyperplasia (ADH), ductal carcinoma in situ (DCIS), and lobular neoplasia (LN), represent an heterogeneous entity with a lot of problems associated with the definition, classification, diagnosis and management of patients [1-5]. The diagnosis of these lesions represents a clinical dilemma for the patient and the physicians $[2,3,5]$. Following a diagnosis of atypical hyperplasia or DCIS, a patient is immediately considered at high risk for future development of invasive breast carcinoma, although this progression will only occur in a portion of patients [6,7]. Uncertainties in the prognosis have given rise to a debate surrounding the appropriate treatment, involving a wide range of treatment approaches from observation to mastectomy. This has resulted in diverse and confusing clinical recommendations, distressing to both patients and clinicians $[3,8,9]$.

The use of molecular markers in the common clinical practice seems promising for the diagnosis and prognostication. Molecular markers nowadays seem to have the potential to improve our ability to care for patients with, or at risk for, breast cancer.

The aim of this review article is to describe the current theories regarding the pathogenesis and molecular evolution of preinvasive breast lesions. With respect to the molecules implicated, this article focuses especially on whether they confer additional risk for invasive breast cancer or 
not. The evaluation of molecular markers is performed under the light of their potential usefulness in treatment decisions presenting in the common clinical practice.

\section{Precursors and preinvasive lesions of the breast}

ADH represents a proliferative lesion that fulfils some, but not all the criteria for a diagnosis of low-grade, noncomedo type DCIS $[2,10]$. In essence, $\mathrm{ADH}$ is usually small and focal, measuring less than 2 to $3 \mathrm{~mm}$. ADH is a rare condition, being seen in $4 \%$ of symptomatic benign biopsies [1]. The significance of the diagnosis of ADH lies in the increased risk of subsequent invasive breast carcinoma (relative risk $\mathrm{RR}=4.4$ ) [10]. When ADH is combined with a positive family history, the relative risk of invasive cancer reaches $9.7[11,12]$. The major problem with regard to $\mathrm{ADH}$ is the difficulty in achieving acceptable levels of concordance or consistency in diagnosis. There is significant inter-observer [13] variability in the diagnosis of ADH. It should also always be born in mind that proliferation at the edge of a biopsy may represent the periphery of a more established lesion of DCIS [1].

DCIS is defined as a proliferation of malignant epithelial cells within the breast parenchymal structures with no evidence of invasion across the basement membrane [1]. Presently, DCIS constitutes $15-20 \%$ of screen-detected malignancies of the breast $[14,15]$, and it is known that such a diagnosis confers an 8-10-fold elevated risk for the development of IBC [16]. Studies suggest that up to 50\% of patients with microscopic foci of DCIS develop invasive carcinoma $[1,6,7]$. Additionally, it has been shown that progression to invasion is related to the subtype of DCIS; comedo disease progresses into invasive carcinoma both more often and more rapidly than low-grade DCIS $[1,17]$.

LN is characterized by the proliferation of generally small and often loosely cohesive cells. The term LN refers to the entire spectrum of atypical epithelial proliferations originating in the terminal duct-lobular unit (TDLU), with or without pagetoid involvement of terminal ducts $[2,4]$. The designations ALH and LCIS, have been widely used for varying degrees of the lesions $[2,18,19]$. $\mathrm{LN}$ is a "marker of increased risk" rather than a true precursor of invasive carcinoma. ALH confers a 3-fold elevated risk for the development of IBC, while LCIS has a relative risk equal to 7 $[2,20]$. LN is multicentric in as many as $85 \%$ of patients and bilateral in $30 \%$ of women who had undergone bilateral mastectomy $[2,4,19,20]$.

\section{Histological models of the progression to invasive carcinoma}

Over the past twenty years, a histological model of human breast cancer evolution was predominant $[21,22]$. The multistep model of breast carcinogenesis supports a transition from normal epithelium to invasive carcinoma via non-atypical hyperplasia, atypical hyperplasia and in situ carcinoma $[4,23,24]$. Confirmatory evidence that precursors and preinvasive lesions are clonal processes arises from studies showing similar genetic changes in lowgrade DCIS and ADH (Table 1), and identical genetic abnormalities with synchronous ipsilateral invasive breast cancer $[4,25-34]$. These studies were supported by mouse mammary tumor models [35] and by epidemiological studies [36] which showed that the risk for breast cancer increased with the rate of proliferation and atypia in breast biopsies. The fact that the invasive carcinoma occurs in the same area as the original indicates a precursor progress $[1,39]$.

On the other hand, the lack of direct evidence for the linear progression model gave birth to new models. Farabegoli et al. [40] proved that DCIS is a possible, but not an obligate precursor of invasive breast cancer and suggest that pure DCIS and DCIS associated with IDC may be genetically distinct. The evolution from DCIS to IDC may thus follow multiple pathways rather than a linear model. Leong et al. suggested that in most cases, low-grade DCIS is associated with low-grade invasive carcinoma and highgrade DCIS with high-grade invasive carcinoma, i.e., horizontal progression. They postulated that intermediategrade DCIS is heterogeneous and it is therefore possible that this group represents some cases of DCIS that have progressed from low-grade DCIS as well as cases that may progress to high-grade DCIS, suggesting that progression may not be entirely horizontal in intermediate-grade DCIS [39-43].

\section{Classification}

All cases of ADH, LN, and DCIS do not have the same possibility to progress to invasive carcinoma $[1,6,7]$. It became thus obvious that a uniform approach is incorrect, and a subclassification arose. However, there is no specific classification for ADH and LN, while for DCIS the Van Nuys classification is the most widely accepted method for risk estimation and has replaced the Holland, the Bellamy, the Leal and the Lagios classifications [39]. The Van Nuys Prognostic Index (VNPI) combines three significant predictors of local recurrence: tumor size, margin width, and pathologic classification (nuclear grade, comedo-type necrosis). According to the VNPI, DCIS is classified into three groups with low, intermediate, or high risk of local recurrence after breast conserving therapy [44].

\section{Molecular markers}

It has become apparent that the existing classification systems of precursors and preinvasive lesions are not adequate. The challenge lies in using available clinical and pathologic data to estimate the individual relative risk for invasive breast carcinoma rather than the relative risk of 
Table I: Genetic predisposition in ADH, LN, DCIS.

\begin{tabular}{|c|c|c|}
\hline \multicolumn{3}{|c|}{ Genetic predisposition } \\
\hline & Losses & Gains \\
\hline ADH: & Iq, 2p, 6q, 9p, IIp, IIq, 13q, 14q, 16q, I7p, I7q, Xq & Unknown \\
\hline ALH: & $11 q, 16 p, 16 q, 17 p, 22 q$ & $6 q$ \\
\hline DCIS: & Ip, 7q, 2p, 2q, 3p, 3q, 4p, 6p, 6q, 7p, 7q, 8p, 8q, 9p, IIp, IIq, I2p, 13q, 14q, 15q, 16p, 16q, I7p, I7q, I8q, $21 \mathrm{q}$ & $1 \mathrm{q}, 3 \mathrm{q}, 6 \mathrm{q}, 6 \mathrm{p}, 8 \mathrm{q}, 17 \mathrm{q}, 20 \mathrm{q}, \mathrm{Xq}$ \\
\hline LCIS: & $11 q, 13 q, 16 p, 16 q, 17 p, 17 q, 22 q$ & $6 q$ \\
\hline
\end{tabular}

each lesion. This could be helpful for the selection of the most appropriate therapy for each individual patient. In the following pages, the available data with respect to important molecules are presented in detail. Table 2 summarizes the main features regarding the presented molecules.

\section{Estrogen receptors (ER)}

Estrogens play a central role in the growth and differentiation of normal breast epithelium, stimulating cell proliferation and regulating the expression of other genes, including the progesterone receptor (PgR) [45-47]. In the normal pre-menopausal breast, ER(+) cells comprise the $7 \%$ of the total epithelial cell population [48]. ER(+) cells are luminal epithelial cells, evenly distributed, and seem to secrete factors which paracrinely influence the proliferation of the adjacent ER(-) cells $[48,49]$. It should be noted that ER positivity and proliferation (as depicted by ki-67 expression, see below) are almost mutually exclusive in normal epithelial breast tissue [49]. ER+ cells increase with age, reaching a plateau after menopause [50].

The intensity of ER expression in the normal epithelium is a risk factor for breast cancer, conferring a 3-fold increase in risk [51]. More specifically, regarding non-atypical epithelial hyperplasia, ER positivity together with ki-67 expression, seem to make an important distinction between lesions: the existence of ki-67(+)/ER(+) cells seems to correlate with progression to more severe lesions [52]. Alternatively, it has been suggested that an increased percentage of ER(+) cells in the adjacent normal lobules seems to be associated with elevated risk for invasive breast cancer rather than ER-positivity within the lesion per se [53].

In other benign breast lesions, such as sclerosing adenosis, radial scars, papillomas, fibroadenomas, and phylloides tumours, the percentage of ER(+) cells is higher than normal breast tissue [54]. Similarly, ER-alpha expression has been proven significantly elevated in the hyperplastic enlarged lobular unit (HELU), which represents the earliest histologically identifiable lesion with premalignant potential. On the contrary, as far as enlarged lobular units with columnar alteration (ELUCA) are concerned, an intriguing result emerged, since more intense ER-alpha staining has been associated with a lower risk of subsequent invasive carcinoma in these lesions [55].

In the context of $\mathrm{ADH}, \mathrm{LN}$ and DCIS, and contrary to the normal breast, ER(+) cells are surrounded by contiguous cells characterized also by ER-positivity [49]. Moreover, in DCIS, the above explained diptych $\mathrm{ER}(+) / \mathrm{Ki}-67(+)$ is a

Table 2: Molecular markers and their prognostic value in precursors and preinvasive breast lesions.

\begin{tabular}{ll}
\hline Molecular markers & Prognostic importance \\
\hline $\begin{array}{l}\text { Estrogen receptor-alpha } \\
\text { Estrogen receptor-beta }\end{array}$ & $\begin{array}{l}\text { Aggravating, 3-fold increased risk for IDC (normal breast epithelium) } \\
\text { Protective }\end{array}$ \\
c-erb-B2 & Aggravating -not unanimous results with respect to RR \\
P53 disruption & Aggravating - conflicting results regarding the RR of its expression in \\
benign lesions & Aggravating - no specific estimation of RR \\
Ki-67 & Aggravating - no specific estimation of RR \\
VEGF & Aggravating \\
E-cadherin disruption & Aggravating \\
TGF- beta & Ambiguous - loss of TGF-beta-RII is aggravating \\
P16 disruption & Controversial findings \\
P2I (WafI) & Controversial findings \\
P27 disruption & Aggravating/scarcity of data \\
14-3-3 sigma hypermethylation & Aggravating \\
\end{tabular}


hallmark [54]. In general, non-comedo carcinomas exhibit more frequently ER positivity $[56,57]$.

In parallel, the less studied ER-beta, seems also to be of importance and to exhibit an inverse pattern to that of ERalpha, declining during the progression from normal breast tissue to ADH, DCIS, and IDC [58,59]. Of notice, according to a recent article, a high ratio ER-alpha/ER-beta in non-atypical epithelial hyperplasia seems to predict progression to carcinoma [60]. Finally, for the optimal envisagement of the ER network, it should be kept in mind that important regulators exist, such as hsp-27 [61] or AIB1 [62], exhibiting more intense expression in breast cancer.

\section{Progesterone receptors (PR)}

Similarly to estrogen receptors, progesterone receptors (PR) have been found elevated very early in premalignant breast lesions, at the hyperplastic enlarged lobular unit (HELU) [63]. On the other hand, a decreasing trend for PR expression has been documented along with progression to malignancy [64]. In DCIS, PR positivity is associated with ER positivity and lack of comedo necrosis [6567]. Concerning PR positivity, studies are contradictory with respect to tumor grade $[65,66,68,69]$ and recurrence rate [[70-72], reviewed in ([72])]. In IDC, progesterone receptors have been associated with histological grade, but not with lymph node involvement, tumor size, or prognosis of the patients [64]. With respect to lobular neoplasia, there is scarcity of data; PR seem however to be expressed in the majority of cases $[74,75]$.

More interestingly however, it is the ratio progesterone receptor A (PRA)/progesterone receptor B (PRB) which seems to play a central role. In normal breast tissue and non-atypical hyperplasia, receptors are homogenously coexpressed, but early during progression, one receptor (especially PRA in advanced lesions) predominates at a heterogeneous manner [76]. Indeed, the physiological role of PRA predominance has been supported by in vitro studies, demonstrating its modulating effects on cell morphology and adhesion $[77,78]$. Of notice, in the normal tissue of BRCA mutation carriers, PRB isoform is strikingly absent [79].

\section{C-erbB-2 (Her-2/neu)}

HER-2/neu, a gene located on $17 \mathrm{q}$, encodes for c-erbB-2 oncoprotein, a tyrosine kinase receptor. Alterations of cerbB2 (HER-2/neu) are suggested to be an important event in malignant transformation [80-82]. According to a variety of studies, c-erbB-2 has not been found overexpressed at the protein level in benign proliferative breast disease or ADH [83-86]. However, amplification of Her-2/ Neu has been documented with the use of FISH in ADH, supporting the notion that the degree of HER-2/neu amplification increases with progression to carcinoma [87]. Accordingly, patients with benign breast lesions showing low levels of amplification of the HER-2 gene have a two-fold increased risk of breast cancer [88]; however, according to another study, c-erbB-2 overexpression in benign lesions was not a significant risk factor [89].

With respect to lobular neoplasia, one fourth of LCIS cases have been found positive for c-erbB-2, irrespectively of the coexistence of an invasive component [90]. Occasional positivity has been found also in pleomorphic lobular (ductal-lobular carcinomas in situ [91].

As far as the role of c-erbB-2 in DCIS is concerned, C-erbB2 immunoreactivity has been primarily associated with DCIS of higher grade, in the absence [63] or presence [92] of IDC, and with comedo type [93]. Interestingly, given the association of higher grade with c-erb-B2 amplification, the latter has been regarded as an independent prognostic factor [94]. Allred et al [95] documented that the percentage of c-erb-B2 immunoreactivity is significantly higher in DCIS than IDC: one of the possible explanations the authors gave was that c-erb-B2 may be more important for the initiation than the progression of breast cancer, or that c-erb-B2 may be downregulated during the progression of breast cancer.

\section{p53}

P53 is a tumour suppressor gene located on 17p. p53 protein mediates its tumor suppressor functions via the transcriptional regulation or repression of a variety of genes [96-98] and is an important component of breast cancer pathophysiology [99]. Regarding the role of p53 as a risk factor in benign breast lesions, there is controversy of data: the immunohistochemical detection of p53 in benign breast lesions has been associated with elevated cancer risk [89], although there are studies with conflicting results [100].

Considering the various types of lesions in the continuum between benign lesions and breast cancer, various studies have assessed the role of p53. In epithelial hyperplasia without atypia, p53 mutations have not been detected [101]. In ADH, the presence and role of p53 mutations is still an open field: p53 mutations were initially not documented [102]; then, studies pointing to p53 mutations appeared [103], and, more recently, the presence of mutated p53 in ADH has been demonstrated with the use of laser capture microdissection microscope, singlestranded conformational polymorphism (SSCP) and sequencing [104]. Regarding LN, there is scarcity of data: in two studies, no p53 immunoreactivity was demonstrated in LN lesions $[105,106]$, whereas a more recent one on LCIS reported p53 immunoreactivity in one fifth of cases [90]. 
p53 mutations/accumulation are present in a significant percentage of DCIS [107-111], especially in the comedo type [112]. However, the clinical significance of p53 accumulation remains still elusive; although it has been found to influence the proliferation rate [113], a recent study showed that it does not affect the proliferation rate of the DCIS lesion per se [107]. Of notice, the coexistence of DCIS with IDC is not associated with a different degree of p53 immunostaining [114].

\section{Ki-67}

$\mathrm{Ki}-67$ is a cell cycle-associated nuclear protein, which is expressed in all cycle phases, with the exception of G0 and early G1, and reacts with MIB-1 antibody [115]. Protein $\mathrm{Ki}-67$ is extensively used as a proliferative index and is linked with malignancy, even in FNA specimens [116]. Moreover, its intrinsic association with apoptosis (bcl-2 status, see below) and p53 expression (see above) seems to be of importance in the diagnosis and prognosis of precursors and preinvasive breast lesions: low Ki-67 expression/bcl-2 positivity and p53 negativity are a trait of ADH and, subsequently, well-differentiated carcinomas. On the contrary, high Ki-67 expression/bcl-2 negativity within the lobules implicate lesions with a potential of poorly differentiated carcinoma [117]. As mentioned above, also in the context of non-atypical hyperplasia, high Ki-67 and ER-alpha expression seem to predict progression to cancer [51,118].

Interestingly enough, a clinical application of Ki-67 expression intensity seems to emerge. In non-atypical ductal hyperplasia, lesions with high Ki-67 expression can be clinically detected scintimammographically, since high (99m)Tc-(V)DMSA uptake seems to be their feature. According to the authors, this could prove useful in identifying women with benign but high-risk breast pathologies [119].

\section{$\mathrm{BCl}-2$}

The bcl-2 gene is located on $18 \mathrm{q}$. Bcl-2 protein, belongs to a family of proteins playing a central role in the regulation of apoptosis [reviewed in ([120]), [121,122]] and other pathways [reviewed in ([123])]. With respect to the overall role of apoptosis in breast cancer pathogenesis, there seems to be an intriguing pattern incorporating the proliferation of the lesion. Growth imbalance in favour of proliferation seems crucial in the transition from normal epithelium to hyperplasia and later, from preinvasive lesions to IDC. On the contrary, apoptosis becomes more important at an intermediate stage: in the transition from hyperplasia to preinvasive lesions, the imbalance is in favour of apoptosis [124]. Bcl-2 is present in the whole spectrum of breast lesions: predominantly in benign lesions, ADH, LN, and well-differentiated DCIS [105,125127]. More specifically, there is a gradual increase in the extent of apoptosis $[124,128]$ and a parallel decrease in bcl-2 expression in benign/precursors/preinvasive/invasive lesions as they become histologically more aggressive [128]. Bcl-2 positivity tends to coincide with p53 negativity in normal breast tissue, non-atypical ductal hyperplasia, $\mathrm{ADH}, \mathrm{LN}$ and in the majority of the DCIS [105]. The role of $\mathrm{Bcl}-2$ expression as a risk factor for breast cancer is described above, together with Ki-67 (see above).

\section{Vascular endothelial growth factor (VEGF) and angiogenesis}

VEGF is a potent angiogenic growth factor, commonly involved in tumor-induced angiogenesis, with a putative therapeutical significance in the context of breast cancer [129]. Of notice, VEGF gene polymorphisms have been associated with modified breast cancer risk in various populations $[130,131]$.

Viacava et al have thoroughly examined the angiogenesis in precursor and preinvasive lesions. Increased vascularization is present in all preinvasive lesions and increases with lesion severity. In ductal lesions, angiogenesis is more intense in poorly/intermediately differentiated intraductal carcinomas than in non-atypical ductal hyperplasia and ADH. Similarly, LCIS, showing microvascular density similar to that of poorly/intermediately differentiated intraductal carcinoma, is more vascularized than ALH. In the same study, VEGF expression in normal glandular structures was lower than in lesions, with the highest levels found in ductal lesions. Interestingly, no correlation was found between VEGF expression and the degree of vascularization in that study [132]. On the other hand, Hieken TJ et al. suggested that VEGF expression may help predict the biologic aggressiveness of DCIS [133]. Additionally, in the context of DCIS, Vogl et al support VEGF expression is not regulated by the HER2 pathway [134].

\section{E-cadherin}

E-cadherin, a tumor suppressor gene located on 17q, has been implicated especially in lobular breast cancer molecular pathogenesis [135]. In clinical practice, immunohistochemistry for E-cadherin is a helpful marker for differential diagnosis, since most cases of low-grade DCIS exhibit E-cadherin positivity, whereas LN is almost always E-cadherin negative [[136], reviewed in ([137]), ([138])]. This implies that E-cadherin disruption is an early event, prior to progression, in lobular carcinogenesis $[139,140]$; more specifically, DNA alterations accompanying the loss of protein expression pertain to LCIS but not to ALH [140]. As expected according to the above, only few studies have focused on E-cadherin in ductal lesions. In the context of DCIS, hypermethylation of E-cadherin 5' CpG islands has been demonstrated [141], and, at the protein level, E-cadherin has been linked to better differentiation [142]. Moreover, mutational analysis of E-cadherin pro- 
vided evidence to support that DCIS is the precursor of invasive ductal carcinoma in cases where LCIS coexists [143].

\section{TGF-beta}

The transforming growth factor-beta (TGF- $\beta$ ) pathway has ambivalent importance in the pathogenesis of breast cancer [reviewed in ([144])]. Serum TGF-beta levels do not differ between patients with breast cancer, DCIS and benign lesions [145]; however, TGF-beta expression becomes more accentuated in IDC, compared with DCIS [146]. Surprisingly enough, an interesting study recently showed that loss of TGF-beta-RII expression in epithelial cells of hyperplasia without atypia is associated with increased risk of IDC [147]. No reports exist on ADH and $\mathrm{LN}$, to our knowledge.

\section{PI6 (INK4a)}

p16 is an inhibitor of cyclin-dependent kinases 4 and 6 [reviewed in ([148])]. With respect to the role of p16, controversial results exist. According to some authors, aberrant methylation of p16 is not demonstrated in benign conditions, epithelial hyperplasia and intraductal papillomas, but is restricted in cancerous epithelium [149]. On the contrary, another study showed that IDC demonstrate hypomethylation of p16 and hyperactivity of the p16 gene (enhanced expression of p16 mRNA), contrary to the hypermethylated, inactive state in the normal epithelium. [150]. Independently, Di Vinci et al. distinguish between p16 hypermethylation and p16 protein overexpression; the former seems not to be specifically associated with malignancy and to occur both in benign and malignant lesions, whereas the latter, together with cytoplasmic sequestration, is a feature of breast carcinoma. [151]. In the context of such controversy, no studies exist with respect to $\mathrm{p} 16$ as a risk factor, with the exception of a study in Poland envisaging p16 as a low penetrance breast cancer susceptibility gene [152].

\section{p27 (Kipl)}

The p27 gene encodes for an inhibitor of the cyclin - CDK (cyclin-dependent kinase) active complex, Although numerous studies exist with respect to the role of p27 in breast cancer [reviewed in ([153]), ([154]), ([155])], there is lack of data regarding precursors, preinvasive lesions and other predisposing conditions. p27 expression has been documented in DCIS, but its clinicopathological significance is still uncertain [156].

\section{P2I (Wafl)}

p21 is a cell cycle regulator, implicated in a variety of pathways [157]. p21 immunoreactivity has been detected both in benign and malignant epithelium, and thus its role is hard to interpret. [126]. Studies focusing especially on $\mathrm{ADH}$, or LN do not exist. As far as DCIS is concerned, p21 positivity has been independently associated with clinical recurrence [158]. On the other hand, Oh YL et al. found a significant correlation between positive $\mathrm{p} 21$ immunoreactivity (67.3\% of the cases) and well-differentiated histologic grade, non-comedo type, ER-positive and p53negativity. According to them, DCIS with p21+/p53- is likely to be the non-comedo type [156].

\section{4-3-3 sigma}

Umbricht et al identified 14-3-3 sigma as a gene whose expression is lost in breast carcinomas, primarily by methylation-mediated silencing. Importantly, the hypermethylation of the locus was absent in hyperplasia without atypia, but was detectable with increasing frequency as the breast lesions progressed from atypical hyperplasia to DCIS, and finally to invasive carcinoma [159]; of notice, methylated alleles existed in the periductal stromal breast tissue. Afterwards, a parallel, stepwise reduction at the 143-3 sigma protein level has been documented [160].

Despite the emerging role of 14-3-3 sigma in breast carcinogenesis, to date no studies exist assessing its role as a risk factor for breast cancer development.

\section{Therapeutic decision - perspectives}

The evaluation of the molecules whose importance has been to date elucidated could be adjunctively useful in the therapeutic decision. A simultaneous presentation of more than one aggravating factors might detect preinvasive lesions at risk of progressing to malignancies and influence the clinical decisions, such as prophylactic surgery (lumpectomy versus mastectomy for excision of the diseased ducts before the development of invasive carcinoma), and chemo-prophylaxis.

For the future of the preinvasive breast lesions' management, it is tempting to anticipate the gradual integration of their molecular profiling in the clinical practice. The simultaneous evaluation of multiple genes has recently appeared for the detection of healthy individuals at risk for breast cancer [161] and will be of special interest also in the context of ADH or LN. An appropriate combination of techniques (immunohistochemistry, fluorescent in situ hybridisation, analysis of LOH, CGH, DNA microarrays proteomics analysis, etc) might be helpful in this direction.

\section{Conclusion}

The clinician should be aware of recent progresses in molecular biology, individualising his approach to every patient based on her own risk factors, tumour markers, histological profile, psychological and social status, etc. With respect to the molecular markers presented above, this article reviews the progress made, but also the existing controversies which should be further studied. Indeed, 
the existing controversies are particularly significant, and point to the need for further research.

\section{Abbreviations}

ADH: atypical ductal hyperplasia,

DCIS: ductal carcinoma in situ,

LN: lobular neoplasia,

R.R: relative risk,

IBC: invasive breast carcinoma,

TDLU: terminal duct-lobular unit,

VNPI: Van Nuys Prognostic Index,

ER: Estrogen receptors

HELU: hyperplastic enlarged lobular unit,

ELUCA: enlarged lobular units with columnar alteration,

PR: Progesterone receptors,

VEGF: Vascular endothelial growth factor

\section{Competing interests}

The author(s) declare that they have no competing interests.

\section{Authors' contributions}

Flora Zagouri: writing of the manuscript, conception of the idea, review of the literature

Theodoros N. Sergentanis: revised the manuscript, writing of the manuscript

George C. Zografos: revised the manuscript critically for important intellectual content, final approval of the version to be published.

\section{References}

I. Pinder SE, Ellis IO: The diagnosis and management of pre-invasive breast disease: ductal carcinoma in situ (DCIS) and atypical ductal hyperplasia (ADH)-current definitions and classification. Breast Cancer Res 2003, 5:254-257.

2. Van de Vijver MJ, Peterse $H$ : The diagnosis and management of pre-invasive breast disease: pathological diagnosis - problems with existing classifications. Breast Cancer Res 2003, 5:269.

3. Purushotham AD: The diagnosis and management of pre-invasive breast disease: problems associated with management of pre-invasive lesions. Breast Cancer Res 2003, 5:309-3I2.

4. Reis-Filho JS, Lakhani SR: The diagnosis and management of pre-invasive breast disease: genetic alterations in pre-invasive lesions. Breast Cancer Res 2003, 5:313-319.

5. Jeffrey SS, Pollack JR: The diagnosis and management of preinvasive breast disease: promise of new technologies in understanding pre-invasive breast lesions. Breast Cancer Res 2003, 5:320-328.

6. Betsill WL Jr, Rosen PP, Lieberman PH, Robbins GF: Intraductal carcinoma. Long-term follow-up after treatment by biopsy alone. JAMA 1978, 239: I863-I867.

7. Page DL, Dupont WD, Rogers LW, Landenberger M: Intraductal carcinoma of the breast: follow-up after biopsy only. Cancer 1982, 49:751-758.

8. Schnitt SJ: The diagnosis and management of pre-invasive breast disease: flat epithelial atypia - classification, pathologic features and clinical significance. Breast Cancer Res 2003, 5:263-268.

9. Boecker W, Moll R, Dervan P, Buerger H, Poremba C, Diallo RI, Herbst H, Schmidt A, Lerch MM, Buchwalow IB: Usual ductal hyperplasia of the breast is a committed stem (progenitor) cell lesion distinct from atypical ductal hyperplasia and ductal carcinoma in situ. J Pathol 2002, 198:458-467.

10. Dupont WD, Parl FF, Hartmann WH, Brinton LA, Winfield AC, Worrell JA, Schuyler PA, Plummer WD: Breast cancer risk associated with proliferative breast disease and atypical hyperplasia. Cancer 1993, 7 I: I 258-1265.

II. Oyama T, Maluf H, Koerner F: Atypical cystic lobules: an early stage in the formation of low-grade ductal carcinoma in situ. Virchows Arch 1999, 435:413-421.

12. Locke I, Mitchell G, Eeles R: Ductal approaches to assessment and management of women at high risk for developing breast cancer. Breast Cancer Res 2004, 6:75-8I.

13. Sloane JP, Ellman R, Anderson TJ, Brown CL, Coyne J, Dallimore NS, Davies JD, Eakins D, Ellis IO, Elston CW, et al.: Consistency of histopathological reporting of breast lesions detected by screening: findings of the U.K. National External Quality Assessment (EQA) Scheme. U. K. National Coordinating Group for Breast. Screening Pathology. Eur J Cancer 1994, 30A:|4|4-14|9.

14. European Commission: European Guidelines for Quality Assurance in Mammography Screening 2nd edition. Luxembourg: Office for Official Publications of the European Communities; 1996.

15. Zografos GC, Panou M, Panou N: Common risk factors of breast and ovarian cancer: recent view. Int J Gynecol Cancer 2004, | 4:72 |-740.

16. Lagios MD: Heterogeneity of duct carcinoma in situ (DCIS): relationship of grade and subtype analysis to local recurrence and risk of invasive transformation. Cancer Lett 1995, 90:97-102.

17. Ketcham AS, Moffat FL: Vexed surgeons, perplexed patients, and breast cancers which may not be cancer. Cancer 1990, 65:387-393.

18. Lishman SC, Lakhani SR: Atypical lobular hyperplasia and lobular carcinoma in situ: surgical and molecular pathology. Histopathology 1999, 35:195-200.

19. Lu YJ, Osin P, Lakhani SR, Di Palma S, Gusterson BA, Shipley JM: Comparative genomic hybridization analysis of lobular carcinoma in situ and atypical lobular hyperplasia and potential roles for gains and losses of genetic material in breast neoplasia. Cancer Res 1998, 58:472 I-4727.

20. Page DL, Schuyler PA, Dupont WD, Jensen RA, Plummer WD Jr, Simpson JF: Atypical lobular hyperplasia as a unilateral predictor of breast cancer risk: a retrospective cohort study. Lancet 2003, 36 I : | 25-129.

21. Buerger H, Otterbach F, Simon R, Poremba C, Diallo R, Decker T, Riethdorf L, Brinkschmidt C, Dockhorn-Dworniczak B, Boecker W: Comparative genomic hybridization of ductal carcinoma in situ of the breast-evidence of multiple genetic pathways. J Pathol 1999, 187:396-402.

22. Dupont WD, Page DL: Risk factors for breast cancer in women with proliferative breast disease. N Engl J Med 1985, 312:|46-15|.

23. Allred DC, Mohsin SK, Fuqua SA: Histological and biological evolution of human premalignant breast disease. Endocr Relat Cancer 200I, 8:47-6I.

24. Moinfar F, Man YG, Bratthauer GL, Ratschek M, Tavassoli FA: Genetic abnormalities in mammary ductal intraepithelial neoplasia-flat type ("clinging ductal carcinoma in situ"): a simulator of normal mammary epithelium. Cancer 2000, 88:2072-2081. 
25. O'Connell P, Pekkel V, Fuqua SA, Osborne CK, Clark GM, Allred DC: Analysis of loss of heterozygosity in 399 premalignant breast lesions at I5 genetic loci. J Natl Cancer Inst 1998, 90:697-703.

26. Noguchi S, Motomura K, Inaji H, Imaoka S, Koyama H: Clonal analysis of predominantly intraductal carcinoma and precancerous lesions of the breast by means of polymerase chain reaction. Cancer Res 1994, 54:1849-1853.

27. Amari M, Suzuki A, Moriya T, Yoshinaga K, Amano G, Sasano H, Ohuchi N, Satomi S, Horii A: LOH analyses of premalignant and malignant lesions of human breast: frequent LOH in 8p, 16q and $17 q$ in atypical ductal hyperplasia. Oncol Rep 1999, 6:1277-1280

28. Gong G, DeVries S, Chew KL, Cha I, Ljung BM, Waldman FM: Genetic changes in paired atypical and usual ductal hyperplasia of the breast by comparative genomic hybridization. Clin Cancer Res 2001, 7:24I0-2414.

29. Moll R, Franke WW, Schiller DL, Geiger B, Krepler R: The catalog of human cytokeratins: patterns of expression in normal epithelia, tumors and cultured cells. Cell 1982, 3II:II-24.

30. Achtstaetter T, Hatzfeld M, Quinlan RA, Parmelee DC, Franke WW: Separation of cytokeratin polypeptides by gel electrophoretic and chromatographic techniques and their identification by immunoblotting. Methods Enzymol I986, 134:355-37I.

31. Moinfar F, Man YG, Lininger RA, Bodian C, Tavassoli FA: Use of keratin 35 betaE 12 as an adjunct in the diagnosis of mammary intraepithelial neoplasia-ductal type - benign and malignant intraductal proliferations. Am J Surg Pathol 1999, 23:1048-1058.

32. Aldaz CM, Chen T, Sahin A, Cunningham J, Bondy M: Comparative allelotype of in situ and invasive human breast cancer: high frequency of microsatellite instability in lobular breast carcinomas. Cancer Res 1995, 55:3976-398I.

33. Tsuda H, Fukutomi T, Hirohashi S: Pattern of gene alterations in intraductal breast neoplasms associated with histological type and grade. Clin Cancer Res 1995, I:26I-267.

34. Cleton-Jansen AM, Moerland HW, Callen DF, Doggett NA, Devilee $\mathrm{P}$, Cornelisse C): Mapping of the breast basic conserved gene (DI6S444E) to human chromosome band I6q24.3. Cytogenet Cell Genet 1995, 68:49-51.

35. Rosai J: Borderline epithelial lesions of the breast. Am J Surg Pathol | 991, I 5:209-22 |

36. Tavassoli FA: Ductal carcinoma in situ: introduction of the concept of ductal intraepithelial neoplasia. Mod Pathol 1998, II:140-154

37. Page DL, Dupont WD, Rogers LW, Landenberger M: Intraductal carcinoma of the breast: follow-up after biopsy only. Cancer 1982, 49:75|-758.

38. Farabegoli F, Champeme MH, Bieche I, Santini D, Ceccarelli C, Derenzini M, Lidereau R: Genetic pathways in the evolution of breast ductal carcinoma in situ. J Pathol 2002, 196:280-286.

39. Leong AS, Sormunen RT, Vinyuvat S, Hamdani RW, Suthipintawong $\mathrm{C}$ : Biologic markers in ductal carcinoma in situ and concurrent infiltrating carcinoma. A comparison of eight contemporary grading systems. Am J Clin Pathol 200 I, I I 5:709-7I8.

40. Lakhani SR, Collins N, Stratton MR, Sloane JP: Atypical ductal hyperplasia of the breast: clonal proliferation with loss of heterozygosity on chromosomes 16q and 17p. I Clin Pathol 1995, 48:6 I I-6I5.

41. Lakhani SR, Slack DN, Hamoudi RA, Collins N, Stratton MR, Sloane JP: Detection of allelic imbalance indicates that a proportion of mammary hyperplasia of usual type are clonal, neoplastic proliferations. Lab Invest 1996, 74:129-135.

42. Buerger H, Otterbach F, Simon R, Schafer KL, Poremba C, Diallo R, Brinkschmidt C, Dockhorn-Dworniczak B, Boecker W: Different genetic pathways in the evolution of invasive breast cancer are associated with distinct morphological subtypes. J Pathol 1999, 189:521-526.

43. Nissan A, Jager D, Roystacher M, Prus D, Peretz T, Eisenberg I, Freund HR, Scanlan M, Ritter G, Old LJ, Mitrani-Rosenbaum S: Multimarker RT-PCR assay for the detection of minimal residual disease in sentinel lymph nodes of breast cancer patients. $\mathrm{Br}$ J Cancer 2006, 94:681-685.

44. Silverstein MJ, Craig PH, Lagios MD, Waisman JK, Lewinsky BS, Colburn W], Poller DN: Developing a prognostic index for ductal carcinoma in situ of the breast. Are we there yet? Cancer 1996, 78: | |38-11140.
45. Henderson BE, Ross R, Bernstein L: Estrogens as a cause of human cancer: the Richard and Hinda Rosenthal Foundation award lecture. Cancer Res 1998, 48:246-253.

46. Pike MC, Spicer DV, Dahmoush L, Press MF: Estrogens, progestogens, normal breast cell proliferation, and breast cancer risk. Epidemiol Rev 1993, 15:17-35.

47. Ali S, Coombes RC: Estrogen receptor alpha in human breast cancer: occurrence and significance. J Mammary Gland Biol Neoplasia 2000, 5:27|-28I.

48. Petersen OW, Hoyer PE, van Deurs B: Frequency and distribution of estrogen receptor-positive cells in normal, nonlactating human breast tissue. Cancer Res 1987, 47:5748-575 I.

49. Clarke RB, Howell A, Potten CS, Anderson E: Dissociation between steroid receptor expression and cell proliferation in the human breast. Cancer Res 1997, 57:4987-499|.

50. Shoker BS, Jarvis C, Clarke RB, Anderson E, Hewlett J, Davies MP, Sibson DR, Sloane JP: Estrogen receptor-positive proliferating cells in the normal and precancerous breast. Am J Pathol 1999 , 155:1811-1815.

5I. Khan SA, Rogers MA, Khurana KK, Meguid MM, Numann PJ: Estrogen receptor expression in benign breast epithelium and breast cancer risk. J Natl Cancer Inst 1998, 90:37-42.

52. Iqbal M, Davies MP, Shoker BS, Jarvis C, Sibson DR, Sloane JP: Subgroups of non-atypical hyperplasia of breast defined by proliferation of oestrogen receptor-positive cells. J Pathol 200I, 193:333-338.

53. Gobbi H, Dupont WD, Parl FF, Schuyler PA, Plummer WD, Olson SJ, Page DL: Breast cancer risk associated with estrogen receptor expression in epithelial hyperplasia lacking atypia and adjacent lobular units. Int J Cancer 2005, I I 3:857-859.

54. Shoker BS, Jarvis C, Clarke RB, Anderson E, Munro C, Davies MP, Sibson DR, Sloane JP: Abnormal regulation of the oestrogen receptor in benign breast lesions. J Clin Pathol 2000, 53:778-783.

55. McLaren BK, Gobbi H, Schuyler PA, Olson SJ, Parl FF, Dupont WD Page DL: Immunohistochemical expression of estrogen receptor in enlarged lobular units with columnar alteration in benign breast biopsies: a nested case-control study. $\mathrm{Am}$ Surg Pathol 2005, 29: 105-108.

56. Bose S, Lesser ML, Norton L, Rosen PP: Immunophenotype of intraductal carcinoma. Arch Pathol Lab Med 1996, I 20:8I-85.

57. Karayiannakis AJ, Bastounis EA, Chatzigianni EB, Makri GG, Alexiou $D$, Karamanakos P: Immunohistochemical detection of oestrogen receptors in ductal carcinoma in situ of the breast. Eur J Surg Oncol 1996, 22:578-582.

58. Roger P, Sahla ME, Makela S, Gustafsson JA, Baldet P, Rochefort H Decreased expression of estrogen receptor beta protein in proliferative preinvasive mammary tumors. Cancer Res 200I, 6I:2537-254I.

59. Shaaban AM, O'Neill PA, Davies MP, Sibson R, West CR, Smith PH, Foster CS: Declining estrogen receptor-beta expression defines malignant progression of human breast neoplasia. Am J Surg Pathol 2003, 27:1502-15I2.

60. Shaaban AM, Jarvis C, Moore F, West C, Dodson A, Foster CS: Prognostic significance of estrogen receptor Beta in epithelial hyperplasia of usual type with known outcome. Am J Surg Pathol 2005, 29:1593-1599.

6I. O'Neill PA, Shaaban AM, West CR, Dodson A, Jarvis C, Moore P, Davies MP, Sibson DR, Foster CS: Increased risk of malignant progression in benign proliferating breast lesions defined by expression of heat shock protein 27. Br J Cancer 2004, 90:182-188.

62. Hudelist G, Czerwenka K, Kubista E, Marton E, Pischinger K, Singer CF: Expression of sex steroid receptors and their co-factors in normal and malignant breast tissue: AIB $I$ is a carcinomaspecific co-activator. Breast Cancer Res Treat 2003, 78:193-204.

63. Lee S, Mohsin SK, Mao S, Hilsenbeck SG, Medina D, Allred DC: Hormones, receptors, and growth in hyperplastic enlarged lobular units: early potential precursors of breast cancer. Breast Cancer Res 2006, 8:R6.

64. Ariga N, Suzuki T, Moriya T, Kimura M, Inoue T, Ohuchi N, Sasano $\mathrm{H}$ : Progesterone receptor $A$ and $B$ isoforms in the human breast and its disorders. Jpn J Cancer Res 200I, 92:302-308.

65. Barnes NL, Boland GP, Davenport A, Knox WF, Bundred NJ: Relationship between hormone receptor status and tumour size, grade and comedo necrosis in ductal carcinoma in situ. $\mathrm{Br}]$ Surg 2005, 92:429-434. 
66. Ringberg A, Anagnostaki L, Anderson H, Idvall I, Ferno M, South Sweden Breast Cancer Group: Cell biological factors in ductal carcinoma in situ (DCIS) of the breast-relationship to ipsilateral local recurrence and histopathological characteristics. Eur Cancer 200I, 37:1514-1522

67. Claus EB, Chu P, Howe CL, Davison TL, Stern DF, Carter D, DiGiovanna MP: Pathobiologic findings in DCIS of the breast: morphologic features, angiogenesis, HER-2/neu and hormone receptors. Exp Mol Pathol 200I, 70:303-3I6.

68. Rody A, Diallo R, Poremba C, Speich R, Wuelfing P, Kissler S, Solbach $C$, Kiesel L, Jackisch C: Estrogen receptor alpha and beta, progesterone receptor, pS2 and HER-2/neu expression delineate different subgroups in ductal carcinoma in situ of the breast. Oncol Rep 2004, 1 2:695-699.

69. Lebrecht A, Buchmann J, Hefler L, Lampe D, Koelbl H: Histological category and expression of hormone receptors in ductal carcinoma in situ of the breast. Anticancer Res 2002, 22:|909-|9|I.

70. Kepple J, Henry-Tillman RS, Klimberg VS, Layeeque R, Siegel E, Westbrook K, Korourian S: The receptor expression pattern in ductal carcinoma in situ predicts recurrence. Am J Surg 2006, | 92:68-7|.

7I. Cornfield DB, Palazzo JP, Schwartz GF, Goonewardene SA, Kovatich A], Chervoneva I, Hyslop T, Schwarting R: The prognostic significance of multiple morphologic features and biologic markers in ductal carcinoma in situ of the breast: a study of a large cohort of patients treated with surgery alone. Cancer 2004 100:2317-2327.

72. Provenzano E, Hopper JL, Giles GG, Marr G, Venter DJ, Armes JE: Biological markers that predict clinical recurrence in ducta carcinoma in situ of the breast. Eur J Cancer 2003, 39:622-630.

73. Nofech-Mozes S, Spayne J, Rakovitch E, Hanna W: Prognostic and predictive molecular markers in DCIS: a review. Adv Anat Pathol 2005, I 2:256-264

74. Fadare O, Dadmanesh F, Alvarado-Cabrero I, Snyder R, Stephen Mitchell J, Tot T, Wang SA, Ghofrani M, Eusebi V, Martel M, Tavassol FA: Lobular intraepithelial neoplasia [lobular carcinoma in situ] with comedo-type necrosis: A clinicopathologic study of I 8 cases. Am J Surg Pathol 2006, 30: I 1445- I 453.

75. Fisher ER, Costantino J, Fisher B, Palekar AS, Paik SM, Suarez CM, Wolmark N: Pathologic findings from the National Surgical Adjuvant Breast Project (NSABP) Protocol B-17. Five-year observations concerning lobular carcinoma in situ. Cancer 1996, 78: |403-1416.

76. Mote PA, Bartow S, Tran N, Clarke CL: Loss of co-ordinate expression of progesterone receptors $A$ and $B$ is an early event in breast carcinogenesis. Breast Cancer Res Treat 2002, 72:163-172.

77. McGowan EM, Clarke CL: Effect of overexpression of progesterone receptor $A$ on endogenous progestin-sensitive endpoints in breast cancer cells. Mol Endocrinol 1999, 13:1657-167|

78. Graham JD, Yager ML, Hill HD, Byth K, O'Neill GM, Clarke CL: Altered progesterone receptor isoform expression remodels progestin responsiveness of breast cancer cells. Mol Endocrinol 2005, 19:27। 3-2735.

79. Mote PA, Leary JA, Avery KA, Sandelin K, Chenevix-Trench G, Kirk JA, Clarke CL, kConFab Investigators: Germ-line mutations in BRCAI or BRCA2 in the normal breast are associated with altered expression of estrogen-responsive proteins and the predominance of progesterone receptor A. Genes Chromosomes Cancer 2004, 39:236-248.

80. De Potter CR, Van Daele S, Van de Vijver MJ, Pauwels C, Maertens G, De Boever J, Vandekerckhove D, Roels H: The expression of the neu oncogene product in breast lesions and in normal fetal and adult human tissues. Histopathology 1989, 15:351-362.

81. Olayioye MA: Update on HER-2 as a target for cancer therapy: intracellular signaling pathways of ErbB2/HER-2 and family members. Breast Cancer Res 200I, 3:385-389.

82. Ross JS, Fletcher JA: HER-2/neu (c-erb-B2) gene and protein in breast cancer. Am J Clin Pathol 1999, I I 2:S53-67.

83. Gusterson BA, Machin LG, Gullick W], Gibbs NM, Powles T], Elliot C, Ashley S, Monaghan P, Harrison S: C-erbB-2 expression in benign and malignant breast disease. $\mathrm{Br} J$ Cancer 1988, 58:453-457.

84. Edorh A, Leroux A, N'sossani B, Parache RM, Rihn B: Detection by immunohistochemistry of c-erbB2 oncoprotein in breast carcinomas and benign mammary lesions. Cell Mol Biol (Noisyle-grand) 1999, 45:83I-840.

85. Aubele $M$, Werner $M$, Hofler $\mathrm{H}$ : Genetic alterations in presumptive precursor lesions of breast carcinomas. Anal Cell Pathol 2002, 24:69-76

86. Heffelfinger SC, Yassin R, Miller MA, Lower EE: Cyclin DI, retinoblastoma, $\mathrm{p} 53$, and Her2/neu protein expression in preinvasive breast pathologies: correlation with vascularity. Pathobiology 2000, 68:129-136.

87. Xu R, Perle MA, Inghirami G, Chan W, Delgado Y, Feiner H: Amplification of Her-2/neu gene in Her-2/neu-overexpressing and -nonexpressing breast carcinomas and their synchronous benign, premalignant, and metastatic lesions detected by FISH in archival material. Mod Pathol 2002, I 5: I |6- 24.

88. Stark A, Hulka BS, Joens S, Novotny D, Thor AD, Wold LE, Schell MJ, Melton LJ 3rd, Liu ET, Conway K: HER-2/neu amplification in benign breast disease and the risk of subsequent breast cancer. I Clin Oncol 2000, 18:267-274.

89. Rohan TE, Hartwick W, Miller AB, Kandel RA: Immunohistochemical detection of c-erbB-2 and p53 in benign breast disease and breast cancer risk. I Natl Cancer Inst 1998, 90: 1262-I 269.

90. Mohsin SK, O'Connell P, Allred DC, Libby AL: Biomarker profile and genetic abnormalities in lobular carcinoma in situ. Breast Cancer Res Treat 2005, 90:249-256.

91. Sneige N, Wang J, Baker BA, Krishnamurthy S, Middleton LP: Clinical, histopathologic, and biologic features of pleomorphic lobular (ductal-lobular) carcinoma in situ of the breast: a report of 24 cases. Mod Pathol 2002, I 5: I044-1050.

92. Tsuda $\mathrm{H}$, Hirohashi S: Multiple developmental pathways of highly aggressive breast cancers disclosed by comparison of histological grades and c-erbB-2 expression patterns in both the non-invasive and invasive portions. Pathol Int 1998, 48:5 I8-525

93. Albonico G, Querzoli P, Ferretti S, Magri E, Nenci I: Biophenotypes of breast carcinoma in situ defined by image analysis of biological parameters. Pathol Res Pract 1996, 192: I 17-123.

94. Tsuda H, Iwaya K, Fukutomi T, Hirohashi S: p53 mutations and cerbB-2 amplification in intraductal and invasive breast carcinomas of high histologic grade. Jpn J Cancer Res 1993, 84:394-40I.

95. Allred DC, Clark GM, Molina R, Tandon AK, Schnitt SJ, Gilchrist KW, Osborne CK, Tormey DC, McGuire WL: Overexpression of HER$2 /$ neu and its relationship with other prognostic factors change during the progression of in situ to invasive breast cancer. Hum Pathol 1992, 23:974-979.

96. Toledo F, Wahl GM: Regulating the p53 pathway: in vitro hypotheses, in vivo veritas. Nat Rev Cancer 2006, 6:909-923.

97. Green DR, Chipuk JE: p53 and metabolism: Inside the TIGAR. Cell 2006, I 26:30-32.

98. Vogelstein B, Lane D, Levine AJ: Surfing the p53 network. Nature 2000, 408:307-310.

99. Gasco M, Shami S, Crook T: The $\mathbf{p} 53$ pathway in breast cancer. Breast Cancer Res 2002, 4:70-76.

100. Younes M, Lebovitz RM, Bommer KE, Cagle PT, Morton D, Khan S, Laucirica R: p53 accumulation in benign breast biopsy specimens. Hum Pathol 1995, 26:155-158.

I0I. Done SJ, Arneson NC, Ozcelik H, Redston M, Andrulis IL: p53 mutations in mammary ductal carcinoma in situ but not in epithelial hyperplasias. Cancer Res 1998, 58:785-789.

102. Chitemerere M, Andersen TI, Holm R, Karlsen F, Borresen AL, Nesland JM: TP53 alterations in atypical ductal hyperplasia and ductal carcinoma in situ of the breast. Breast Cancer Res Treat 1996, 41:103-109.

103. Kang JH, Kim SJ, Noh DY, Choe KJ, Lee ES, Kang HS: The timing and characterization of $\mathrm{p} 53$ mutations in progression from atypical ductal hyperplasia to invasive lesions in the breast cancer. J Mol Med 2001, 79:648-655.

104. Keohavong P, Gao WM, Mady HH, Kanbour-Shakir A, Melhem MF: Analysis of p53 mutations in cells taken from paraffinembedded tissue sections of ductal carcinoma in situ and atypical ductal hyperplasia of the breast. Cancer Lett 2004, 212:121-130

105. Siziopikou KP, Prioleau JE, Harris JR, Schnitt SJ: bcl-2 expression in the spectrum of preinvasive breast lesions. Cancer 1996, 77:499-506 
106. Sapino A, Frigerio A, Peterse JL, Arisio R, Coluccia C, Bussolati G Mammographically detected in situ lobular carcinomas of the breast. Virchows Arch 2000, 436:42I-430.

107. Lebeau A, Unholzer A, Amann G, Kronawitter M, Bauerfeind I, Sendelhofert A, Iff A, Lohrs U: EGFR, HER-2/neu, cyclin DI, p2I and p53 in correlation to cell proliferation and steroid hormone receptor status in ductal carcinoma in situ of the breast. Breast Cancer Res Treat 2003, 79:187-198.

108. Tan PH, Chuah KL, Chiang G, Wong CY, Dong F, Bay BH: Correlation of $\mathrm{p} 53$ and cerbB2 expression and hormonal receptor status with clinicopathologic parameters in ductal carcinoma in situ of the breast. Oncol Rep 2002, 9:1081-1086.

109. Megha T, Ferrari F, Benvenuto A, Bellan C, Lalinga AV, Lazzi S, Bartolommei S, Cevenini G, Leoncini L, Tosi P: p53 mutation in breast cancer. Correlation with cell kinetics and cell of origin. J Clin Pathol 2002, 55:46I-466.

1 10. Bartley AN, Ross DW: Validation of p53 immunohistochemistry as a prognostic factor in breast cancer in clinical practice. Arch Pathol Lab Med 2002, I 26:456-458.

III. Poller DN, Roberts EC, Bell JA, Elston CW, Blamey RW, Ellis IO: p53 protein expression in mammary ductal carcinoma in situ: relationship to immunohistochemical expression of estrogen receptor and c-erbB-2 protein. Hum Pathol 1993, 24:463-468.

I I2. O'Malley FP, Vnencak-Jones CL, Dupont WD, Parl F, Manning S, Page $\mathrm{DL}$ : p53 mutations are confined to the comedo type ductal carcinoma in situ of the breast. Immunohistochemical and sequencing data. Lab Invest I994, 7 I:67-72.

I 13. Rudas M, Neumayer R, Gnant MF, Mittelbock M, Jakesz R, Reiner A: p53 protein expression, cell proliferation and steroid hormone receptors in ductal and lobular in situ carcinomas of the breast. Eur J Cancer 1997, 33:39-44.

II4. Mylonas I, Makovitzky J, Jeschke U, Briese V, Friese K, Gerber B: Expression of Her2/neu, steroid receptors (ER and PR), Ki67 and p53 in invasive mammary ductal carcinoma associated with ductal carcinoma In Situ (DCIS) Versus invasive breast cancer alone. Anticancer Res 2005, 25:1719-1723.

II5. Gerdes J, Lemke H, Baisch H, Wacker HH, Schwab U, Stein H: Cell cycle analysis of a cell proliferation-associated human nuclear antigen defined by the monoclonal antibody Ki-67. J Immunol 1984, 133:1710-1715.

116. Midulla C, Pisani T, De lorio P, Cenci M, Divizia E, Nofroni I, Vecchione $A$ : Cytological analysis and immunocytochemical expression of $\mathrm{Ki67}$ and $\mathrm{Bcl}-2$ in breast proliferative lesions. Anticancer Res 2002, 22:134|-1345.

117. Viacava P, Naccarato AG, Bevilacqua G: Different proliferative patterns characterize different preinvasive breast lesions. Pathol 1999, 188:245-251.

1 18. Shaaban AM, Sloane JP, West CR, Foster CS: Breast cancer risk in usual ductal hyperplasia is defined by estrogen receptoralpha and Ki-67 expression. Am J Pathol 2002, I 60:597-604.

119. Papantoniou V, Tsiouris S, Koutsikos J, Sotiropoulou M, Mainta E, Lazaris D, Valsamaki P, Melissinou M, Zerva C, Antsaklis A: Scintimammographic detection of usual ductal breast hyperplasia with increased proliferation rate at risk for malignancy. Nucl Med Commun 2006, 27:91 I-917.

120. van Delft MF, Huang DC: How the Bcl-2 family of proteins interact to regulate apoptosis. Cell Res 2006, 16:203-2।3.

12I. Reed JC: Bcl-2 and the regulation of programmed cell death J Cell Biol 1994, I 24: I-6.

122. Hockenbery DM: bcl-2 in cancer, development and apoptosis. J Cell Sci Suppl 1994, 18:5I-55.

123. Kim R: Unknotting the roles of Bcl-2 and Bcl-xL in cell death. Biochem Biophys Res Commun 2005, 333:336-343.

124. Bai M, Agnantis NJ, Kamina S, Demou A, Zagorianakou P, Katsaraki $A$, Kanavaros $P$ : In vivo cell kinetics in breast carcinogenesis. Breast Cancer Res 200I, 3:276-283.

125. Kapucuoglu N, Losi L, Eusebi V: Immunohistochemical localization of $\mathrm{BCl}-2$ and $\mathrm{Bax}$ proteins in in situ and invasive duct breast carcinomas. Virchows Arch 1997, 430:17-22.

126. Krogerus LA, Leivonen M, Haasto AL: Expression patterns of biologic markers in small breast cancers and preneoplastic breast lesions. Breast 2000, 9:28I-285.

127. Meteoglu I, Dikicioglu E, Erkus M, Culhaci N, Kacar F, Ozkara E, Uyar M: Breast carcinogenesis. Transition from hyperplasia to invasive lesions. Saudi Med J 2005, 26: | 889- 8896.
128. Mustonen M, Raunio H, Paakko P, Soini Y: The extent of apoptosis is inversely associated with bcl-2 expression in premalignant and malignant breast lesions. Histopathology 1997, 3 1:347-354.

129. Sledge GW Jr: VEGF-targeting therapy for breast cancer. Mammary Gland Biol Neoplasia 2005, 10:3 19-323.

130. Kataoka N, Cai Q, Wen W, Shu XO, Jin F, Gao YT, Zheng W: Population-based case-control study of VEGF gene polymorphisms and breast cancer risk among Chinese women. Cancer Epidemiol Biomarkers Prev 2006, I 5: I | 48-I I 52.

I3I. Jacobs EJ, Feigelson HS, Bain EB, Brady KA, Rodriguez C, Stevens VL, Patel AV, Thun MJ, Calle EE: Polymorphisms in the vascular endothelial growth factor gene and breast cancer in the Cancer Prevention Study II cohort. Breast Cancer Res 2006, 8:R22.

132. Viacava $P$, Naccarato AG, Bocci G, Fanelli G, Aretini P, Lonobile $A$, Evangelista G, Montruccoli G, Bevilacqua G: Angiogenesis and VEGF expression in pre-invasive lesions of the human breast. J Pathol 2004, 204: | 40-146.

133. Hieken TJ, Farolan M, D'Alessandro S, Velasco JM: Predicting the biologic behavior of ductal carcinoma in situ: an analysis of molecular markers. Surgery 200I, 130:593-600. discussion 600-I

134. Vogl G, Dietze O, Hauser-Kronberger C: Angiogenic potential of ductal carcinoma in situ (DCIS) of human breast. Histopathology 2005, 47:617-624.

135. Berx G, Cleton-Jansen AM, Nollet F, de Leeuw WJ, van de Vijver M, Cornelisse C, van Roy F: E-cadherin is a tumour/invasion suppressor gene mutated in human lobular breast cancers. EMBO J 1995, 14:6107-6115.

136. Bratthauer GL, Moinfar F, Stamatakos MD, Mezzetti TP, Shekitka KM, Man YG, Tavassoli FA: Combined E-cadherin and high molecular weight cytokeratin immunoprofile differentiates lobular, ductal, and hybrid mammary intraepithelial neoplasias. Hum Pathol 2002, 33:620-627.

137. Lerwill MF: Current practical applications of diagnostic immunohistochemistry in breast pathology. Am J Surg Pathol 2004, 28:|076-109|.

138. Putti TC, Pinder SE, Elston CW, Lee AH, Ellis IO: Breast pathology practice: most common problems in a consultation service. Histopathology 2005, 47:445-457.

139. Vos CB, Cleton-Jansen AM, Berx G, de Leeuw WJ, ter Haar NT, van Roy F, Cornelisse CJ, Peterse JL, van de Vijver MJ: E-cadherin inactivation in lobular carcinoma in situ of the breast: an early event in tumorigenesis. $\mathrm{Br} /$ Cancer 1997, 76: I |3 I- II33.

140. Mastracci TL, Tjan S, Bane AL, O'Malley FP, Andrulis IL: E-cadherin alterations in atypical lobular hyperplasia and lobular carcinoma in situ of the breast. Mod Pathol 2005, 18:74I-75I.

14I. Nass SJ, Herman JG, Gabrielson E, Iversen PW, Parl FF, Davidson NE, Graff JR: Aberrant methylation of the estrogen receptor and E-cadherin 5' CpG islands increases with malignant progression in human breast cancer. Cancer Res 2000, 60:4346-4348.

142. Gupta SK, Douglas-Jones AG, Jasani B, Morgan JM, Pignatelli M, Mansel RE: E-cadherin (E-cad) expression in duct carcinoma in situ (DCIS) of the breast. Virchows Arch 1997, 430:23-28.

143. Rieger-Christ KM, Pezza JA, Dugan JM, Braasch JW, Hughes KS, Summerhayes IC: Disparate E-cadherin mutations in LCIS and associated invasive breast carcinomas. Mol Pathol 200I, 54:91-97.

144. Wakefield LM, Piek E, Bottinger EP: TGF-beta signaling in mammary gland development and tumorigenesis. J Mammary Gland Biol Neoplasia 200I, 6:67-82.

145. Lebrecht A, Grimm C, Euller G, Ludwig E, Ulbrich E, Lantzsch T, Hefler L, Koelbl H: Transforming growth factor beta I serum levels in patients with preinvasive and invasive lesions of the breast. Int J Biol Markers 2004, 19:236-239.

|46. Walker RA, Dearing SJ: Transforming growth factor beta I in ductal carcinoma in situ and invasive carcinomas of the breast. Eur J Cancer 1992, 28:641-644.

147. Gobbi H, Dupont WD, Simpson JF, Plummer WD Jr, Schuyler PA Olson SJ, Arteaga CL, Page DL: Transforming growth factorbeta and breast cancer risk in women with mammary epithelial hyperplasia. J Natl Cancer Inst 1999, 91 :2096-2 I0I.

148. Rocco JW, Sidransky D: pl 6(MTS-I/CDKN2/INK4a) in cancer progression. Exp Cell Res 200I, 264:42-55.

149. Lehmann U, Langer F, Feist H, Glockner S, Hasemeier B, Kreipe H, (Krassenstein R, Sauter E, Dulaimi E, Battagli C, Ehya H, Klein-Szanto $A$, Cairns P: Detection of breast cancer in nipple aspirate fluid 
by CpG island hypermethylation. Clin Cancer Res 2004, I0:28-32.

150. Van Zee KJ, Calvano JE, Bisogna M: Hypomethylation and increased gene expression of pI6INK4a in primary and metastatic breast carcinoma as compared to normal breast tissue. Oncogene 1998, 16:2723-2727.

15I. Di Vinci A, Perdelli L, Banelli B, Salvi S, Casciano I, Gelvi I, Allemanni G, Margallo E, Gatteschi B, Romani M: pI6(INK4a) promoter methylation and protein expression in breast fibroadenoma and carcinoma. Int J Cancer 2005, I | 4:4| 4-2I.

152. Debniak T, Gorski B, Huzarski T, Byrski T, Cybulski C, Mackiewicz A, Gozdecka-Grodecka S, Gronwald J, Kowalska E, Haus O, Grzybowska E, Stawicka M, Swiec M, Urbanski K, Niepsuj S, Wasko B, Gozdz S, Wandzel P, Szczylik C, Surdyka D, Rozmiarek A, Zambrano O, Posmyk M, Narod SA, Lubinski J: A common variant of CDKN2A (p16) predisposes to breast cancer. J Med Genet 2005, 42:763-765.

153. Colozza M, Azambuja E, Cardoso F, Sotiriou C, Larsimont D, Piccart MJ: Proliferative markers as prognostic and predictive tools in early breast cancer: where are we now? Ann Oncol 2005, 16:1723-1739.

154. Alkarain A, Jordan R, Slingerland J: p27 deregulation in breast cancer: prognostic significance and implications for therapy. J Mammary Gland Biol Neoplasia 2004, 9:67-80.

155. Musgrove EA, Davison EA, Ormandy CJ: Role of the CDK inhibitor p27 (KipI) in mammary development and carcinogenesis: insights from knockout mice. J Mammary Gland Biol Neoplasia 2004, 9:55-66.

156. Oh YL, Choi JS, Song SY, Ko YH, Han BK, Nam SJ, Yang JH: Expression of p2IWafI, P27KipI and cyclin DI proteins in breast ductal carcinoma in situ: Relation with clinicopathologic characteristics and with p53 expression and estrogen receptor status. Pathol Int 2001, 5 I:94-99.

157. Dotto GP: p2I(WAFI/CipI): more than a break to the cell cycle? Biochim Biophys Acta 2000, I 47 I:M43-56.

158. Provenzano E, Hopper JL, Giles GG, Marr G, Venter DJ, Armes JE: Biological markers that predict clinical recurrence in ductal carcinoma in situ of the breast. Eur J Cancer 2003, 39:622-630.

159. Umbricht CB, Evron E, Gabrielson E, Ferguson A, Marks J, Sukumar S: Hypermethylation of 14-3-3 sigma (stratifin) is an early event in breast cancer. Oncogene 200I, 20:3348-3353.

160. Simooka H, Oyama T, Sano T, Horiguchi J, Nakajima T: Immunohistochemical analysis of 14-3-3 sigma and related proteins in hyperplastic and neoplastic breast lesions, with particular reference to early carcinogenesis. Pathol Int 2004, 54:595-602.

161. Gerger A, Langsenlehner U, Renner W, Weitzer W, Eder T, YazdaniBiuki B, Hofmann G, Samonigg H, Krippl P: A multigenic approach to predict breast cancer risk. Breast Cancer Res Treat 2006 in press.

\section{Publish with Bio Med Central and every scientist can read your work free of charge}

"BioMed Central will be the most significant development for disseminating the results of biomedical research in our lifetime. "

Sir Paul Nurse, Cancer Research UK

Your research papers will be:

- available free of charge to the entire biomedical community

- peer reviewed and published immediately upon acceptance

- cited in PubMed and archived on PubMed Central

- yours - you keep the copyright

Submit your manuscript here:

http://www.biomedcentral.com/info/publishing_adv.asp
BioMedcentral 